\title{
MICROSURGERY IN THE NETHERLANDS, FROM AN EXPERIMENTAL PHARMACOLOGICAL PERSPECTIVE
}

\author{
R. Remie ${ }^{1,2}$, I.M. Cuesta Cobo ${ }^{1}$, E.N. Spoelstra ${ }^{1}$ \\ ${ }^{1}$ René Remie Surgical Skills Centre, Almere, the Netherlands \\ ${ }^{2}$ Microsurgical Developments Foundation, Maastricht, the Netherlands
}

This paper is dedicated to the memory of Hans Rensema (1948-2020), medical artist of Microsurgical Developments Foundation.

The history of training in microsurgical and experimental techniques in the Netherlands goes back to the 1960s. The training was mostly done on an individual basis. Clinical surgeons could benefit from the 'Wet-Lab' training at the Erasmus University of Rotterdam. Experimental microsurgery and techniques training for larger groups of bio-technicians and researchers started at Utrecht University in 1993, and later at Groningen University. The first commercial training was offered at the International Microsurgical Training Centre in Lelystad (IMTC,) in 2002. This paper presents the current state-of-the-art training in the Netherlands and some future perspectives.

Professor Remie studied Pharmacy at the University of Groningen. After completing his studies in 1983, he specialised in pharmacology and did his $\mathrm{PhD}$ on the presynaptic modulation of noradrenergic neurotransmission in the freely moving rat portal vein. He joined Solvay Pharmaceuticals as a Group leader in Pharmacology, specialised (1991) in Laboratory Animal Science (Utrecht University), and became Laboratory Animal Scientist and Animal Welfare Officer of Solvay Pharmaceuticals and Fort Dodge Animal Health Holland. He is chairman of the Microsurgical Developments Foundation and several IACUCs. From 1997 until 2012, he was appointed professor with a special chair in Microsurgery and Experimental Technique in Laboratory Animals at the Groningen Centre for Drug Research, Department of Biomonitoring \& Sensoring, University Centre for Pharmacy, University of Groningen. He is CEO of 3-R's Training Centre BV, and Director of the René Remie Surgical Skills Centre (www.rrssc.eu).

Irene Cuesta Cobo earned a BSc in Biology and physiotherapy, and an MSc in manual therapy at the University of Jaén (Spain). She worked at the department of physiology at the same university on an in-vivo assay with gliomas in rats and subsequently, at the Laboratory of CAR Madrid to analyse top athletes' blood samples. She is a senior instructor at RRSSC.

Edwin Spoelstra earned an MSc in Pharmacy and specialised stereotaxic surgery and microdialysis in the rat. He developed several techniques in mice and spent the last ten years on catheter design and blood-sampling.

Keywords:

Conflict of interest:

Financial disclosure:

For citation: experimental techniques, microsurgery training, rats, mice, animal models, $3 R$ s.

the authors declare the absence of obvious and potential conflicts of interest related to the publication of this paper.

no author has a financial or property interest in any material or method metioned.

Remie R., Cuesta Cobo I.M., Spoelstra E.N. Microsurgery in the Netherlands, from an experimental pharmacological perspective. Issues of Reconstructive and Plastic Surgery. 2021;24(1):39-47. doi: 10.52581/1814-1471/76/4

\section{МИКРОХИРУРГИЯ В НИДЕРЛАНДАХ С ЭКСПЕРИМЕНТАЛЬНОЙ ФАРМАКОЛОГИЧЕСКОЙ ТОЧКИ ЗРЕНИЯ}

\author{
Р. Реми ${ }^{1,2}$, И.М. Куэста Кобо ${ }^{1}$, Е.Н. Споэмьстра ${ }^{1}$ \\ ${ }^{1}$ Центр хирургических навыков Рене Реми, г. Алмере, Нидерланды \\ ${ }^{2}$ Фонд разработок в области микрохирургии, г. Маастрихт, Нидерланды
}


Эта статья посвящена памяти Ганса Ренсема (1948-2020), медицинского художника Фонда разработок в области микрохирургии.

История обучения микрохирургическим и экспериментальным методикам в Нидерландах восходит к 1960-м гг. Обучение в основном проходило индивидуально. КАинические хирурги могми пройти курс обучения «Wet-Lab» в Университете Эразма в Роттердаме. Обучение экспериментальной микрохирургии и метоАам Аля больших групп биотехников и исследователей началось в Утрехтском университете в 1993 г., а затем в Гронингенском университете. Первое обучение на коммерческой основе состоялось в МежАународном учебном центре микрохирургии (IMTC) в АелистаАе в 2002 г. В настоящей статье преАставлены современные методы обучения микрохирургии в Нидерландах и некоторые перспективы на будущее.

Профессор Реми изучал фармацию в Гронингенском университете. После завершения учебы в 1983 г. он специализировался на фармакологии и защитил диссертацию на степень $\mathrm{PhD}$ по пресинаптической модумяции норадренергической нейротрансмиссии в свободно Авижущейся воротной вене крысы. Он присоединился к Solvay Pharmaceuticals в качестве руководителя группы по фармакологии, специализировался в области мабораторных животных (Утрехтский университет, 1991) и стал специалистом по мабораторным животным и защите животных в Solvay Pharmaceuticals и Fort Dodge Animal Health Holland. Профессор Реми явмяется председателем Фонда микрохирургических разработок и нескольких Институциональных комитетов по уходу и использованию животных (IACUC). В период с 1997 по 2012 г. Рене Реми явцялся профессором специальной кафедры микрохирургии и экспериментальной техники на мабораторных животных в Гронингенском центре исследований мекарственных среАств, а также кафеАры биомониторинга и сенсорики Университетского центра фармацевтики Гронингенского университета. Он является генеральным директором Учебного центра 3-R's Training Center BV и директором Центра хирургических навыков Рене Реми (www.rrssc.eu).

Ирен Куэста Кобо получила степень бакалавра биологии и физиотерапии, а также магистра мануальной терапии в Университете Хаэн (Испания). Работала на кафеАре физиологии в том же университете с глиомами у крыс in vivo, а затем в маборатории CAR Madrid, гАе занималась анализом образцов крови спортсменов. Является старшим инструктором Центра хирургических навыков Рене Реми.

ЭАвин Споэльстра получим степень магистра фармацевтики и специализированной стереотаксической хирургии и микродиализа на крысах. Разработал несколько методов на мышах. Последние 10 мет посвятил разработке Аизайна катетеров и исследованиям крови.

Ключевые слова:

Конфмикт интересов:

Прозрачность финансовой Аеятельности:

Амя цитирования: экспериментальные методы, обучение микрохирургии, крысы, мыши, животные модемu, 3Rs.

авторы подтвержАают отсутствие конфмикта интересов, о котором необходимо сообщить.

никто из авторов не имеет финансовой заинтересованности в преАставленных материалах ими методах.

Реми Р., Куэста Кобо И.М., Споэльстра Е.Н. Микрохирургия в Нидерландах с экспериментальной фармакологической точки зрения. Вопросы реконструктивной и пластической хирургии. 2021;24(1):39-47. doi: 10.17223/18141471/76/4

\section{THE BEGINNING}

The introduction of the (operating) microscope and the fundamental techniques of vascular anastomosis were indispensable throughout the history of microsurgery. Implementation of the operating microscope led to a revolution in almost every surgical discipline. Nylén, a clinical assistant in otorhinolaryngology in Karolinska Medical School, first recognised the need for magnification in ear surgery and used a monocular microscope in a few chronic cases of otitis and pseudo-fistula formation in 1921. Holmgren (1923) reported the first microsurgical fenestration for otosclerosis using a binocular operating microscope. Therefore, otorhinolaryngology is considered to be the cradle of microsurgery. Without the operating microscope, it could not have been developed to its present state of perfection. In 1951, Littmann, of the Carl-Zeiss Co., manufactured a prototype of the OpMi-1, a microscope equipped with coaxial illumination for use as a colposcope or otoscope, still used today. It became commercially available in 1953 when it began to be used quite rapidly and increased in the operating room [35].

In 1902, Alexis Carrel first performed end-toend (ETE) vascular anastomosis by hand using a '3-stay suture technique', a fundamental vascular surgery technique (see R.F. Rickard and D.A. Hudson, 2014 [31] for a historical overview). Jacobson and Suarez (1960) published a brief historical article on microsurgery for 1-mm blood vessel anastomosis. Recognising the difficulty in doing this with the naked eye, they introduced the operating microscope into small vascular surgery. 
Work in experimental microsurgery began in the late 1950s. Dr Sun Lee (Korean name Sil Heung Lee) the renowned "Father of Microsurgery", was born in Korea and emigrated to the USA in 1950. At that time, rats were seldom used in surgical laboratories, despite a long history of rat usage in allied biological research. Encouraged by Dr Fisher, Dr Lee started his pioneer experiments, performing portacaval shunts in rats in 1957, using end-to-side anastomosis. After many attempts and failures, Lee perfected an end-to-side portacaval shunt in 1958, thus creating the discipline of experimental microsurgery. Microsurgery opened an avenue to conducting allied physiological research and transplantation investigation. In those early years, Lee started to develop kidney and hearttransplantation models in the rat, and in the years that followed, many organs were transplanted between different rat strains. His research raised immunology, then in its infancy, to unknown heights. Today, $95 \%$ of organ-transplantation research projects are performed using small rodents. Professor Sun Lee died on October 4, 2015 , at the age of 95 .

\section{MICROSURGERY IN THE NETHERLANDS}

The first International Microsurgical Workshop was held on September 4-5, 1970, organised by Dr van Bekkum in Rijswijk. It was the first meeting of the International Microsurgical Society (IMS), and since then it has continued biennially. In those early days, several groups in the Netherlands were using these new microsurgical technique possibilities. At the Erasmus Medical Centre, Drs Kort and Marquet specialised in small bowel, heart and liver transplantation surgery, and trained students in microsurgery in the 'Wet-Lab'. Simultaneously, Drs Hess and Jerusalem at the Radboud University of Nijmegen developed a heterotopic auxiliary liver-transplantation technique. They later worked on fibrous microvascular polyurethane prosthesis [24, 26]. Dr Wildevuur and colleagues at Groningen University worked on experimental microsurgery and focused, a.o., on lung transplantation in the rat. Teaching was mostly limited to individuals or small groups. Dr Remie and Mr Bartels trained several scientists, technicians, and some dental surgeons at Groningen University in the late 1970s.

However, nonclinical biomedical researchers were slow to discover the additional benefits of using the microscope, along with microsurgical techniques. In the early 1970 s, in vivo pharmacological research and drug discovery were performed with few exceptions on anaesthetised animals. Freelymoving animal models were rarely seen. Resear- chers physically restrained the animals, thus circumventing unwanted effects of anaesthetics on the parameters to be measured. Researchers could create freely-moving animal models used for repeated experiments with microsurgery, thus saving many animal lives $[28,29]$.

Today, a quick search on PubMed shows over 2300 papers published on microsurgical training. Interest in the application of microsurgical techniques was stimulated in the mid-1980s during the revival of the concept of the 3-Rs, originally suggested in 1959 by William M.S. Russell and Rex L. Burch in their book "The Principles of Humane Experimental Technique" [32]. Refined surgical techniques in experiments were recommended, leading to an eventual reduction of animal numbers [2, 30]. However, if researchers want to take advantage of microsurgery benefits, they need some tools for learning the proper technique. Hence, we describe the development of several (non-animal) tools for microsurgical training.

\section{MICROSURGICAL DEVELOPMENTS FOUNDATION}

In 1982, a group was formed around several equal-minded people interested in furthering training, in microsurgical and experimental techniques. This group organised the first European Society for Parenteral and Enteral Nutrition (ESPEN) workshop in August 1987. In 1990, the group founded the Microsurgical Developments Foundation (MD, www.microdev.nl).

The main objective of this nonprofit organisation is the production of educational tools for life-sciences research. Since the early papers on microsurgical techniques often lacked a clear and detailed description, we compiled the Manual of Microsurgery on the Laboratory Rat. Experimental and microsurgical techniques are described and illustrated in great detail $[28,29]$. While microsurgery skills can not be mastered purely through books, MD also compiled ten detailed and explicit videotapes of several operations and general techniques used in rats.

When learning microsurgical techniques, it is crucial to develop the ability to concentrate on the visual images seen through the microscope, to use fine instruments, and to coordinate one's movement. At that time, the use of anaesthetised animals was often advocated for training purposes, but it is difficult for students to divide their attention between mastering a technique and taking proper care of the animal. The animals often died untimely, resulting in students feeling disappointed. Due to these and other factors, the number of animals needed in the initial training phase is often remarkably high $[3,16]$. Therefore, during these 
courses, it became apparent that there was a need for a simple device to practice basic techniques.

\section{THE ANASTOMOSIS DEVICE}

Many attempts were made to replace animals for (super) microsurgical training purposes [8, 10, $14,15,20,23,27]$. T. Kaufman et al. (1984) were the first to introduce the foliage leaf for microvascular surgery training [17]. A.M. Awwad (1984) introduced the so-called Practi-Card, which contains 16 small compartments consisting of two cardboard pieces with a small rubber piece in between [4]. Freys and Koob (1988) described a training method for increasingly difficult procedures without using live animals [12]. They started with rubber gloves, continued with silicon tubing, a chicken's sciatic nerve, and ended with a coronary arterial vascular anastomosis of a pig's heart. S. Ayoubi (1992) reported using placentas in microvascular exercises [5]. K.E. Korber and B.A. Kraemer (1989) described using small-calibre Gore-Tex grafts as another alternative for microsurgical training [19].

Our MD-anastomosis device is made of PVC; it is smooth, easy to manufacture, and easy to clean. The device consists of three rings. A surgical glove is clamped between two rings, and the third ring is pushed or pinned over it. Students can be trained in hand-eye coordination, instrument handling, needle and suture handling, placing knots, and ergonomics (the primary body and hand positions to avoid tremor and fatigue). In this stage, we break down all movements to specific elements, e.g. knots are tied in 16 separate steps. After mastering these basics, students can establish interrupted and continuous sutures in various directions. The device can also be used to clamp small-diameter silicone or latex tubing to practice suturing and knotting procedures in standard (ETE) and end-to-side (ETS) anastomoses. By turning the device upside down, the students can simulate suturing in deep cavities.

\section{End-to-end anastomosis (termino-terminal anastomosis)}

Before starting with the anastomosis, the vessel ends must be free from blood or blood clots, best achieved by intraluminal irrigation, with a diluted heparin solution $(5-10 \mathrm{IU} / \mathrm{ml})$ and a blunt $32 \mathrm{G}$ needle. The stay- or corner sutures can be placed in several ways. The most straightforward technique is placing the second stay suture at $180^{\circ}$ from the first, "the symmetric bi-angulation". John Cobbett in England published a paper on the fundamentals of microvascular surgical techniques in 1967, in which he particularly stressed the importance of "eccentric stay suture at 120 degrees" or "asymmetric bi-angulation." Compared with ordinary stay sutures $180^{\circ}$ apart, the needle seldom catches the posterior wall when inserted in the vessel's anterior wall, as the vascular lumen stays open due to the stretching of the stay sutures [9]. However, E. Kim et al. (2016) could not show a significant difference between the bi-angulation and tri-angulation techniques, when done in cryopreserved rat aortas [18]. The tri-angulation was, in fact, a modification of eccentric, asymmetric bi-angulation, as suggested by Alexis Carrel in 1902. The Cobbett technique is used as a standard in our training $[1,7,25]$.

Fig. 1 shows the positioning of the first two sutures, which are placed at '10 o'clock' and at ' 2 o'clock'. By doing this, one can ensure that the vessel's opposite side is not grasped by mistake, thus avoiding a through-stitch. Note that the distance between the needle insertion and the vessel's edge is approximately $0.15-0.25 \mathrm{~mm}$. The bite's size may vary according to the vessel's diameter, the vascular wall's thickness, the suture and needle size. If it is difficult to see the colourless, translucent vessel, place a piece of coloured plastic (blue or yellow) beneath the vessel to better view its fine details. Once the (stay or corner) sutures have been made and tied, some tension must be put at the ends to flatten the vessel wall and expose the anastomosis using small bulldog clamps.

When passing the needle through the vessel wall, do not take the tissue's full thickness between the forceps jaws, as this will cause a great deal of damage. The correct way of passing the needle through is to lift the vessel wall at the adventitia, or place the left-hand forceps on the tissue's underside, and gently push the vessel wall up, which is then easily penetrated.

Subsequently, the needle should pass perpendicularly through the other side of the vessel wall. Again, do not take the entire thickness of the vessel, but take the adventitia, or use the forceps to support the vessel's topside just beyond and beside the place where the needle should emerge. When the needle-holder reaches the tissue, the needle must be released and can be grasped at the other side.

When pulling the needle through the tissues, let it follow its curvature. If one does not do this, the stitch holes will become unnecessarily enlarged. Pull the needle through and let the thread follow the entry-exit line, reducing damage to the tissue by angulating the thread at both the entry and the exit hole. The next suture is placed at 12 o'clock' position (in the middle of the stay sutures) and tied. If the vessel's circumference is divided into equal parts, and the other end of the vessel matches, the edges can be brought together evenly, achieving the optimal result. If not, the anastomosis is des- 
tined to be crude and distorted, and stenosis will often make it unsuccessful.

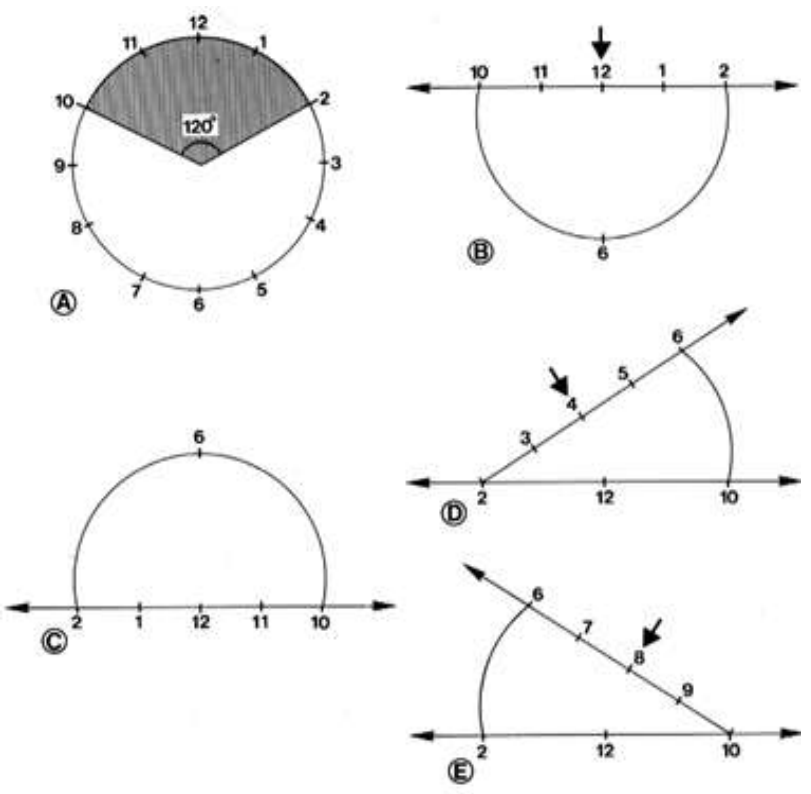

Fig. 1. Schematic drawing of the steps in an ETE anastomosis: A - the corner sutures are placed at $120^{\circ}$ ("2 o'clock" and "10 o'clock"); B - light tension is put on the corner sutures, and the next three sutures are placed. The arrow indicates the first suture to be placed; $\mathrm{C}$ - the anastomosis is rotated, and the "6 o'clock" suture is placed; D the " 6 o'clock" suture is retracted to the right, and the next three sutures are placed; E - the "6 o'clock" suture is retracted to the left, and the anastomosis is completed

Рис. 1. Схематическое изображение этапов анастомоза ETE: A - угмовые швы накмадываются под угмом $120^{\circ}$ (в позиции «2 часа» и «10 часов»); Б - угмовые швы слегка натягивают и накмадывают следующие три шва (стрелкой показан первый шов, который нужно наложить); С - анастомоз поворачивают и накладывают шов «6 часов»; D - шов «6 часов» отводят вправо и наклаАывают слеАующие три шва; E - шов «6 часов» отвеАен влево, анастомоз завершен

After finishing the anterior wall, rotate the vessel, as shown in Fig. 2. There are two ways to do this: rotating the clamps or rotating only the sutures. When possible, clamp rotation is best. Now the anterior wall has become posterior (this was the back wall). Subsequently, place a central suture in the original 6 o'clock position. The next sutures should be placed halfway between 6 o'clock and 2 o'clock, and between 6 o'clock and 10 o'clock, while the 6 o'clock suture is placed under some tension. Depending on the diameter of the vessel, between 6 and 12 sutures should be placed equidistantly. The distance between stitches in a $1-\mathrm{mm}$ artery must be approximately 0.35 to $0.4 \mathrm{~mm}$, meaning that between 6 and 8 stitches are required.

In microsurgery, vessel approximators are frequently used. They are available with and without cleats to hold the stay sutures. A piece of Silastic

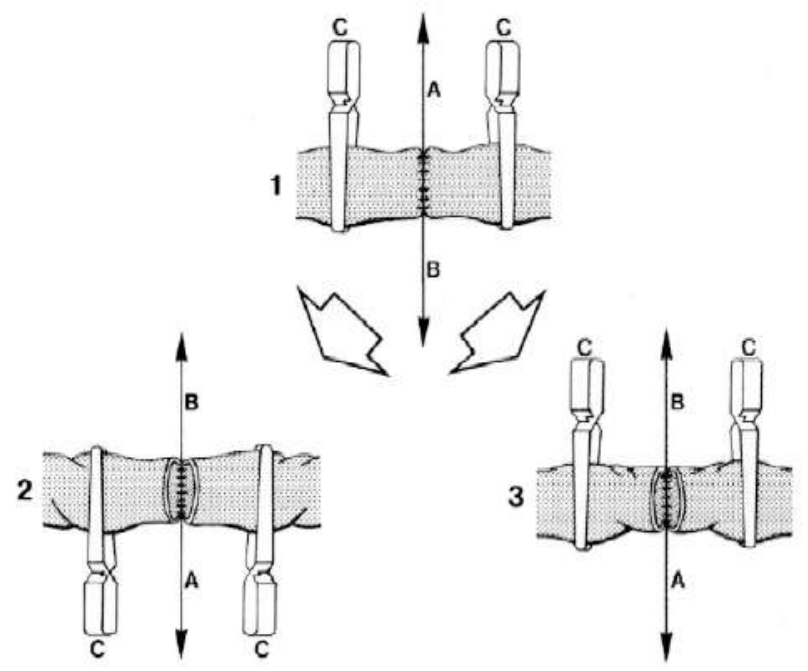

Fig. 2. Rotation of the anastomosis: 1 - the anterior wall has been sutured; 2 - Clamp rotation: the clamps (C) are rotated, and the corner sutures ( $A$ and $B$ ) are repositioned; 3 - Suture rotation: the corner sutures are repositioned, while the clamps retain their position, resulting in slight torsion of the vessel; A and B - Corner sutures; C Clamps.

Рис. 2. Ротация анастомоза: 1 - передняя стенка ушита; 2 - вращение зажима: зажимы (C) повернуты, а угмовые швы (А и В) перемещены; 3 - ротация швов: угловые швы перемещаются, зажимы сохраняют свое положение, что приводит к небольшому перекручиванию сосуАа; А и Б - угмовые швы; С - Зажимы.

tubing (1-2 mm in diameter) or latex will ideally serve as a substitute blood vessel as you begin to master the end-to-end anastomosis technique in experimental microsurgery.

\section{End-to-side anastomosis (termino-lateral an- astomosis)}

After making a hole in the main vessel wall, which corresponds to the side vessel's internal diameter used for the anastomosis, one stay sutures should be placed at 9 o'clock and 3 o'clock, then tied. Using a continuous suture technique, leave the suture's standing end (the one without the needle) a little longer than the working strand, and use it to put some tension on the anastomosis. The other end with the needle is used for suturing. If the vessel cannot be turned over for direct visualisation of the posterior wall, the posterior wall should be sutured first from the inside (Fig. 3).

In case the vessel can be turned over, the anterior wall should be sutured first. Then, after turning over the vessel, which allows the anterior wall to become posterior, the posterior wall can be inspected from the inside. Subsequently, the new anterior wall is sutured, completing the anastomosis. 


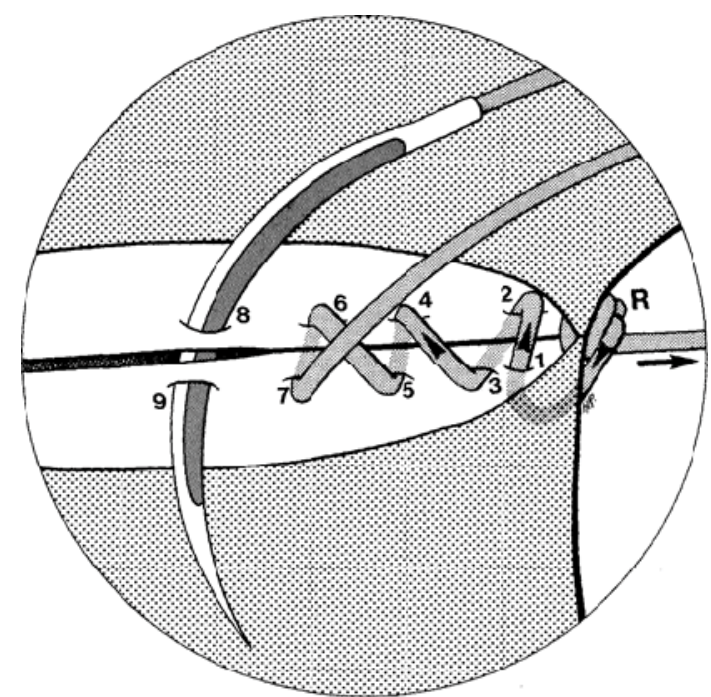

Fig. 3. Detail of the first stitches in the posterior wall: $R$ Corner suture

Рис. 3. Выполнение первых швов задней стенки: $\mathrm{R}$ угмовой шов

\section{The MD PVC-Rat}

After some years of experience with the anastomoses device (Fig. 4), we felt a need for a model to simulate a complete surgical technique. Again, the goal was to separate the attention to the technique and the animal. We discussed several options ranging from a stylistic approach to a true-to-life rat model. With a grant from the Platform Alternatives to Animal Use Program (PAD), Ministry of Public Health, Welfare and Sport in the Netherlands, we started developing in 1994, in close cooperation with Solvay Pharmaceuticals, Solvay Plastics, Unilever, and Museum Technical Works Foundation in Groningen.

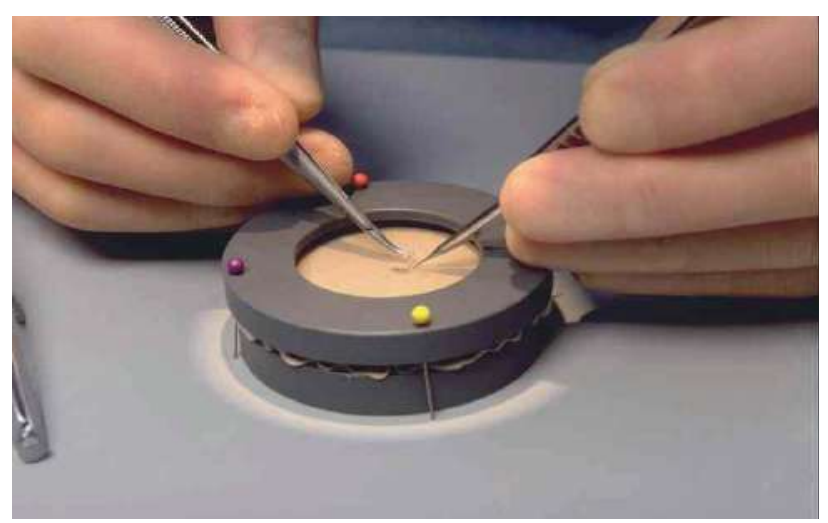

Fig. 4. The anastomoses device in use

Рис. 4. Используемый анастомоз

Several difficulties had to be addressed, such as the most suitable material to make the blood vessels and properly fixate these vessels into the model. We also wanted to produce the MD PVCRat in a cost-efficient way to allow as many people as possible to buy the rat at a low cost. The final model is made of PVC, while blood vessels and other structures are made of latex, and the organs made of polyurethane (Fig. 5).
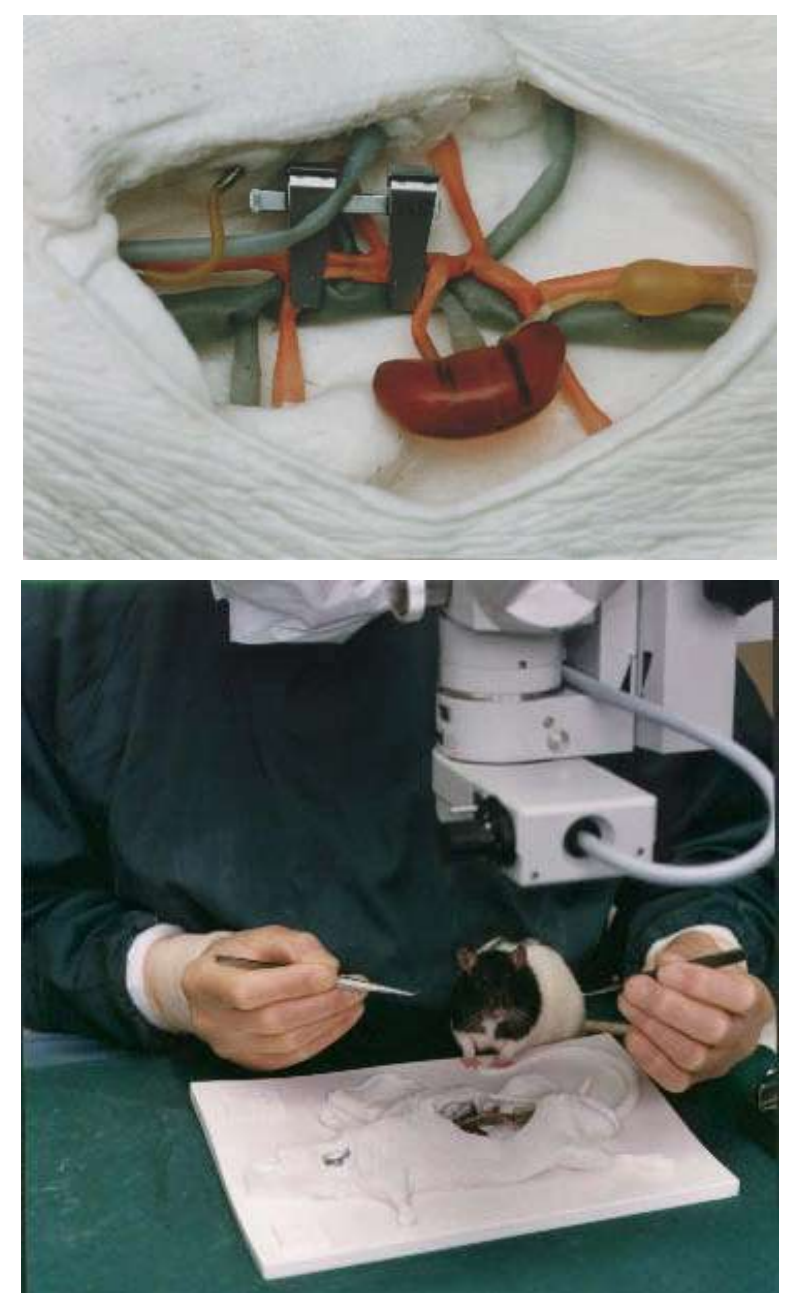

Fig. 5. The MD PVC-Rat

Рис. 5. Анатомическая модель крысы MD PVC-Rat

Both experienced and inexperienced microsurgeons evaluated the model, and we used their comments to improve it. A prototype of the model was presented at the Second World Congress on Alternatives and Animal Use in the Life Sciences, held in Utrecht, in 1996. The final model became available in 1999. The MD PVC-Rat can be used in conjunction with the anastomoses device to train students in more than 25 advanced experimental and microsurgical techniques (e.g., catheterisation of portal, renal, and jugular veins, making portacaval shunts using button and suture techniques, and transplantation of blood vessels, kidneys, and hearts). After mastering the technique, students must be trained in perioperative care (patient monitoring). It is essential to understand that unlike physicians or veterinarians, most scientists are not trained in surgery. Therefore, we decided to develop a computer program that would simulate the anaesthetic process and problems that can occur during surgery. The PAD also funded the 
REMOTE project when the Product-Group BioSimulations of the Van Hall Institute in Leeuwarden designed the software.

Depending on the surgeon's skill, the program will generate problems with parameters such as body temperature, respiratory rate, and heart rate. The student is now forced to concentrate on the animal's welfare, correct the problem, and continue with the technique.

We must also make sure that future scientists, whose research involves surgical intervention in animals, are familiar with the basic principles of aseptic technique. Asepsis is an often-neglected part of the surgery in rats and mice, but it can quickly be learned using the MD PVC-Rat.

After introducing the MD PVC-Rat in our microsurgery courses, we saw further progress in our students' performance. Numerous mistakes that would generally cost animal lives were circumvented, and students felt much more at ease when they perform their first operation on a living animal $[2,30]$. We have found that using the model reduced the number of animals used during scientists and animal-technician training by approximately $90 \%$.

MD was also involved in setting up an introductory microsurgery course at the Department of Laboratory Animal Science (LAS), Utrecht University, in 1993. It was a three-day course in microsurgical and experimental techniques. Until 2001, these courses were given three times a year, one of which was in English, and linked to the International Course on LAS. In 2002 International Microsurgical Training Centre (IMTC) was founded. The Centre could accommodate 16 students. The training was extended to five days, with participants practising a model of their choice with experienced instructors' help on the final day. IMTC stopped in 2009, and 3-R's Training Centre took over under the name RRSSC (www.rrssc.eu).

Anatomical knowledge is crucial when performing experimental microsurgical techniques. Unfortunately, there were no suitable rat anatomical models available in the early 1990s. Therefore, MD started to develop a 3-dimensional, four-times life-size anatomical model of the rat (Fig. 6). In this model, hundreds of anatomical structures are shown, and students can learn the optimal approach to the structures of interest.

Today at RRSSC, we start with training on the anastomosis device and continue in the MD PVCRat. On day two, we focus on vascular catheterisation, followed by super microsurgery on the rat's femoral artery. We repeat this on the third day and add the end-to-end (ETE) of the abdominal aorta. During the last two days of our clinical Module A, we train end-to-side (ETS) anastomosis (portacaval shunt) free-flap transplantation (superficial epigastric artery and vein), and sciatic-nerve repair.
It is a training program similar to the one described by A. Beris et al., 2020 [6].

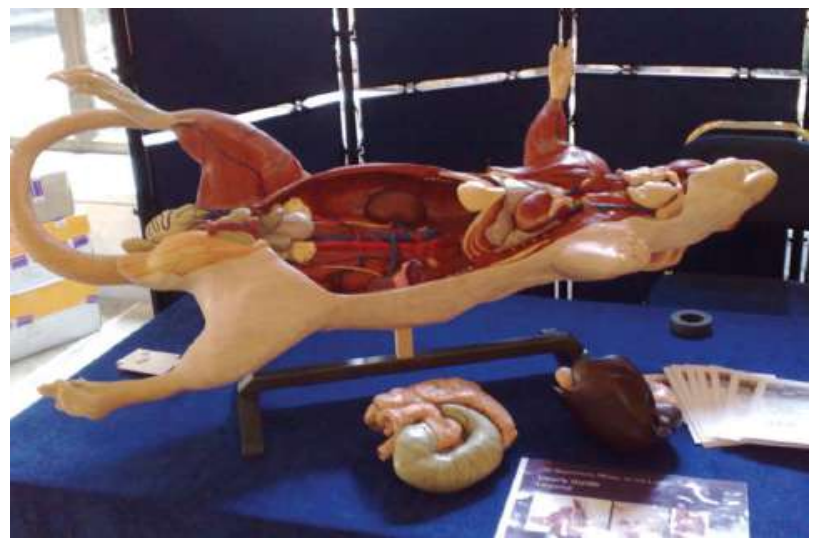

Fig. 6. The MD 3-D anatomical model of the rat

Рис. 6. 3D-анатомическая модель крысы

In Module B for experimental surgery, we focus on participants' needs, e.g. catheterisation techniques, myocardial infarction, transverse aortic constriction, intrathecal administration, CSF sampling, radio-telemetry implants, and many other techniques.

\section{ASSESSMENT TOOLS}

At RRSSC we use the QAPLAS quality assured pedagogy (https://qaplas.net/).

Intended learning outcomes (ILOs), teaching and learning activities (TLAs), assessment criteria (AC) and assessment task/-s (ATs) were identified and described.

In doing so, the course structure was enhanced, specific course obstacles to teaching and learning were identified, and good pedagogy practice versus good laboratory practice and 3R was implemented.

In our courses at the Karolinska Institutet, Stockholm, Sweden, we used a set of assessment tools composed of:

- Instrument choice

- Instrument handling/knowledge

- Suture handling

- Quality of the knot

- Hand position and motion

- Respect for the tissue

- The flow of the operation

- Quality of the final product

We evaluated students during days two and five of the course, to monitor learning. The assessment is best done by an expert who is not involved in the actual training. Several other assessment tools have been developed for clinical microsurgery [36].

\section{ONLINE TRAINING}

Like many other businesses, we are affected by our clients' travel restrictions due to the Corona 
pandemic, and subsequently, the number of course participants being able to follow our training modules has decreased. Although surgical training is best achieved with personal guidance in our dedicated training facilities, we have decided to set up online surgical training for advanced surgeons and expand our training possibilities (Fig. 7).

We have set the highest standard for performing this surgical training online. Both the microscopevision and overview of the surgical area are provided. Moreover, using a portable digital microscope, we offer the possibility of monitoring students while they perform surgery. This allows us to guide them through procedures and help them perform complicated surgical steps. The online communication using Microsoft Teams enables us to invite other specialists into our network to assist. The training sessions are recorded for future reference.

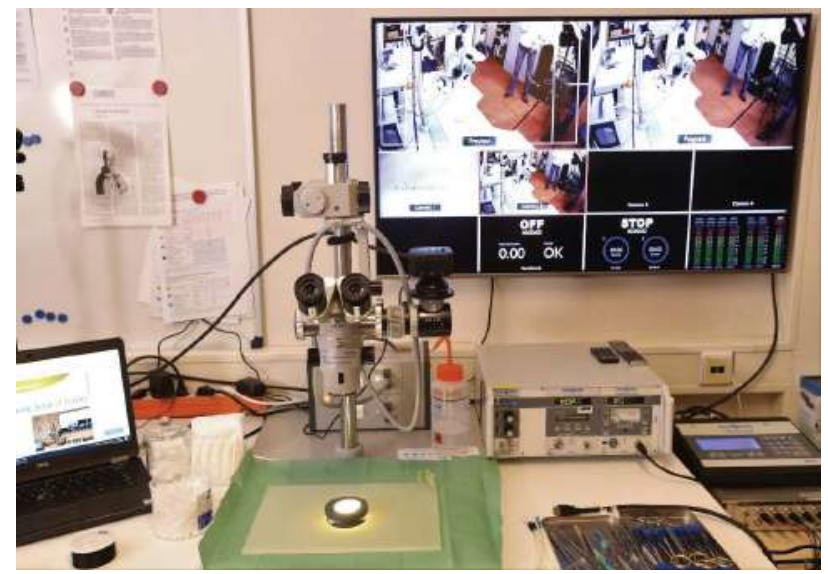

Fig. 7. Online training at RRSSC

Рис. 7. Ониайн-обучение в Центре хирургических навыков Рене Реми

\section{REFERENCES}

1. Acland R.D. MicrosurgeryPractice Manual. The C.V. Mosby Company, St. Louis, Missouri, 1980.

2. Akelina Y. Applying the "3 Rs": Training Course in Surgical Techniques. Lab Animal. 2003;32(1):41-44.

3. Asfar S.K., Catto G.R.D., Engeset J. The rat renal transplantation model. J R Coll Surg Edinb. 1988;33:314-317.

4. Awwad A.M. A training card for microsurgery. Microsurgery. 1984;5:160.

5. Ayoubi S., Wrad P., Naik S., Sankaran M. The use of placenta in microvascular exercise. Neurosurgery. 1992; 30:252-254.

6. Beris A., Kostas-Agnantis I., Gkiatas I., Gatsios D., Fotiadis D., \& Korompilias A. Microsurgery training: A combined educational program. Injury. 2020. Dec;51 Suppl. 4:S131-S134.

7. Biemer E. and Duspiva W. (eds). Rekonstruktive Mikro-gefäßchirurgie. Springer-Verlag, Berlin, Heidelberg, New York, 1980:16-29.

8. Chan W.Y., Matteucci P., Southern S.J. Validation of microsurgical models in microsurgery training and competence: a review. Microsurgery. 2007;27(5):494-499.

9. Cobbett J.R. Microvascular surgery. Surg Clin North Am. 1967;47:521-542.

10. Crossby N.L., Clapson B., Buncke H.J., Newlin L. Advanced non-animal microsurgical exercises. Microsurgery. $1995 ; 16: 655-658$.

11. Di Cataldo A., La Greca G., Rodolico M., Candiano C., Li Destri G., Puleo S. Experimental models in microsurgery. Microsurgery. 1998;18:454-459.

12. Freys S.M., Koob E. Training in microsurgery without the use of live animals. Hand Surg. Microsurg. Plast. Surg. 1988;20:11-16.

13. Fukui A. Microvascular Anastomoses in the Rat. In: Tamai S., Usui M., Yoshizu T. (Eds.) Experimental and Clinical Reconstructive Microsurgery. Springer-Verlag Tokyo, 2003.

14. Grossman B.L., Komatsu D.E., Badalamente M.A., Braunstein A.M., Hurst L.C. Microsurgical Simulation Exercise for Surgical Training. J Surg Educ. 2016 Jan-Feb;73(1):116-120.

15. Ilie V.J., Dobreanu C., Ghetu N., Luchian S., Pieptu D. Training of microsurgical skills on nonliving models. Microsurgery. 2008;28(7):571-577.

16. Hölzen J.P., Palmes D., Langer M., \& Spiegel H.U. Microsurgical training curriculum for learning kidney and liver transplantation in the rat. Microsurgery. 2005;25(8):614-623.

17. Kaufman T., Hurwitz D.J., Ballantyne D.L. The foliage leaf in microvascular surgery. Microsurgery. 1984;5:57-58.

18. Kim E., Singh M., Akelina Y., Shurey S., Myers S.R., Ghanem A.M. Effect of Microvascular Anastomosis Technique on End Product Outcome in Simulated Training: A Prospective Blinded Randomized Controlled Trial. J Reconstr Microsurg. 2016;Sep;32(7):556-561.

19. Korber K.E. and Kraemer B.A. Use of small-calibre polytetrafluoroethylene (Gore-Tex) grafts in microsurgical training. Microsurgery. 1989;10:113-115.

20. Lannon D.A, Atkins J.A, Butler P.E. Non-vital, prosthetic and virtual reality models of microsurgical training. Microsurgery. 2001;21:389-393.

21. Lee S.H. and Fisher B. Portacaval shunt in the rat. Surgery. 1961;50:668-672.

22. Lee S.H. History and development of experimental microsurgery in rats. In: Thiede A., Deltz E., Engemann R., and Hamelmann H., eds. Microsurgical Models in Rats for Transplantation Research. Springer-Verlag, Berlin, 1985:1-10. 
23. Malik M.M., Hachach-Haram N., Tahir M., Al-Musabi M., Masud D., Mohanna P. Acquisition of basic microsurgery skills using home-based simulation training: A randomised control study. J Plast Reconstr Aesthet Surg. 2017 Apr;70(4):478-486.

24. Marquet R., Hess F., Kort W.J., and Boeckx W., eds. Microsurgery: Experimental Techniques in the Rat and Clinical Applications. Ghent, European Press, 1976.

25. O'Brien B.M. Reconstructive microsurgery. Churchill Livingstone, New York, 1987. pp. 31-61.

26. Olszewski W.L. Handbook of Microsurgery, Vol. 2. Boca Raton, FL, CRC Press, 1984.

27. Pafitanis G., Narushima M., Yamamoto T., Raveendran M., Veljanoski D., Ghanem A.M., Myers S., Koshima I. Evolution of an evidence-based supermicrosurgery simulation training curriculum: a systematic review. J Plast Reconstr Aesthet Surg. 2018;Jul;71(7):976-988.

28. Remie R., van Dongen J.J., Rensema J.W., van Wunnik G.H.J. General techniques. In: van Dongen J.J., Remie R., Rensema J.W., and van Wunnik G.H.J., eds. Manual of Microsurgery on the LaboratoryRat. Elsevier Science Publishers BV (Biomedical Division), Amsterdam, 1990:81-159,

29. Remie R., Rensema J.W., and van Wunnik G.H.J., and J.J. van Dongen. General principles of microsurgery. In: van Dongen J.J., Remie R., Rensema J.W, and van Wunnik G.H.J., eds. Manual of Microsurgery on the Laboratory Rat. Elsevier Science Publishers BV (Biomedical Division), Amsterdam, 1990, pp. 11-21.

30. Remie R. The PVC-rat and other alternatives in microsurgical training. Lab Anim. 2001;30(9):48-52.

31. Rickard R.F., Hudson D.A. A History of Vascular and Microvascular Surgery, Annals of Plastic Surgery. October 2014;73(4):465-472.

32. Russell W.M.S. and Burch R.L. The Principles of Humane Experimental Technique. Methuen \& Co., London, 1959.

33. Shurey S., Akelina Y., Legagneux J., Malzone G., Jiga L., Ghanem A.M.: The rat model in microsurgery education: classical exercises and new horizons. Arch Plast Surg. 2014; 41:201-208.

34. Sun Lee. Historical Events on Development of Experimental Microsurgical Organ Transplantation. Yonsei Medical Journal. 2004;45(6):1115-1120.

35. Susumu Tamai. History of Microsurgery-from the beginning until the end of the 1970s. Microsurgery. $1993 ; 14(1): 6-13$.

36. Tolba R., Czigány Z., Osorio Lujan S., Oltean M., Axelsson M., Akelina Y., Di Cataldo A., Miko I., Furka I., Dahmen U., Kobayashi E., Ionac M., Nemeth N. Defining Standards in Experimental Microsurgical Training: Recommendations of the European Society for Surgical Research (ESSR) and the International Society for Experimental Microsurgery (ISEM). Eur Surg Res. 2017;58:246-262.

37. Van Dongen J.J., Bartels H.L., Rensema J.W., Robinson P.H. and Remie R. Training device for microsurgical anastomoses. Anim. Techn. 1996;47:19-27.

Поступила в редакиию 28.12.2020, утверждена к печати 18.02.2021 Received 28.12.2020, accepted for publication 18.02.2021

Information about authors:

René Remie*, PharmD, DLAS, PhD, René Remie Surgical Skills Centre, Almere, the Netherlands; Microsurgical Developments Foundation, Maastricht, the Netherlands.

E-mail: r.remie@rrssc.eu

Irene M. Cuesta Cobo, BSc, MSc, René Remie Surgical Skills Centre, Almere, the Netherlands.

Edwin N. Spoelstra, BSc, MSc, René Remie Surgical Skills Centre, Almere, the Netherlands.

Сведения об авторах:

Рене Реми*, PharmD, DLAS, PhD, Аиректор Центра хирургических навыков Рене Реми, (г. Алмере, Нидерканды), руководитель Фонда разработок в области микрохирургии (г. Маастрихт, Нидерланды).

E-mail: r.remie@rrssc.eu

Ирен М. Куэста Кобо, BSc, MSc, старший инструктор Центра хирургических навыков Рене Реми (г. Алмере, Нидерланды).

ЭАвин Н. Споэлстра, BSc, MSc, сотрудник Центра хирургических навыков Рене Реми (г. Алмере, Нидерланды). 